\title{
Anthropometric measures and nutrition intake, habits and perceptions of Division I women's volleyball players
}

\author{
Danny Cortez ${ }^{1 *}$, Laura Krebs-Holm¹, David Gish², Robert Wildman ${ }^{1}$ \\ From International Society of Sports Nutrition: 8th Annual ISSN Conference and Expo \\ Las Vegas, NV, USA. 24-25 June 2011
}

\begin{abstract}
Background
Volleyball is a physically demanding sport and success is based on aspects speed, power, agility, endurance, rapid processing and focus. Nutrition plays a significant role in maximizing performance and volleyball athletes need to be well-informed. Meanwhile, players can be selfconscious of body size and appearance especially in lieu of body contour revealing uniforms. At this time research-based information of this athletic population with regard to body composition, nutrition intake, habits and perceptions is limited and was studied.
\end{abstract}

\section{Methods}

Twelve Division I women volleyball players aged $18.33 \pm 2.9$ with $8.8 \pm 1.9$ years of competitive volleyball experience participated in a study to assess body weight, composition and self-image as well as nutrition knowledge, perceptions, information resources and intake. Body composition was assessed using BOD POD (Life Measurement, Inc) and a 50-question survey was administered including questions addressing nutrition habits, perceptions and knowledge as well as self-image. Nutrition knowledge questions were validated and multiple choice while answers regarding nutrition and health perceptions and self-image were designed on a Likert scale and ranged from "Strongly Disagree" to "Strongly Agree". Meanwhile a 3-day Food Journal was completed including two weekdays and one weekend day.

\section{Results}

Results of anthropometric measures included height $(176.2 \pm 7.4 \mathrm{~cm})$, weight $(73.3 \pm 6.8 \mathrm{~kg})$, BMI $(23.57 \pm 2.4)$,

${ }^{1}$ Food and Nutrition, School of Family \& Consumer Sciences, Texas State University, San Marcos, TX 78666, USA

Full list of author information is available at the end of the article
FM\% (22.1 $\pm 5.7 \%)$ and FFM\% (77.9 $\pm 5.7 \%)$. The average energy and protein intake was $1577 \pm 451 \mathrm{kcal} /$ day and $1.04 \pm 0.23 \mathrm{~g} / \mathrm{kg}$ with $52 \%, 28 \%, 20 \%$ of energy derived from carbohydrate protein and fat. The average intake of Vitamin $C, B_{1}, B_{2}, B_{3}, B_{6} B_{12}$ and zinc were above DRI recommendations while folate, calcium, iron and magnesium were below. Meanwhile $75 \%$ ofplayers alleged using one or more nutrition supplements $\geq 2$ days/week. Only two of the players had taken a college nutrition course while seven indicated that they dedicated personal time to nutrition study and all ranked their coaches, friends and the internet as the primary sources of nutrition information. However, the players scored $38 \% \pm 12 \%$ of the answers correct on a nutrition questionnaire while ranking water (hydration), protein and then carbohydrate in order of importance to maximizing sport performance. Related to health, $67 \%$ and $33 \%$ alleged never having their blood glucose and blood pressure and lipids checked. Furthermore, $75 \%$ either agreed or strongly agreed that they would like to change the way their body looks and worry about becoming fat while all players disagreed that skipping meals was a good way to control weight.

\section{Conclusion}

In conclusion, the volleyball players assessed were lean on average and most were concerned about body weight and are calorie conscious and have a strong sense of self-image. Meanwhile, average energy intake was below estimated needs while energy distribution suggests emphasis on carbohydrate and protein food choices.

\section{Author details}

'Food and Nutrition, School of Family \& Consumer Sciences, Texas State University, San Marcos, TX 78666, USA. ${ }^{2}$ Department of Health \& Human Performance. Texas State University, San Marcos, TX 78666, USA. 
doi:10.1186/1550-2783-8-S1-P8

Cite this article as: Cortez et al:: Anthropometric measures and nutrition intake, habits and perceptions of Division I women's volleyball players. Journal of the International Society of Sports Nutrition 2011 8(Suppl 1):P8.

Submit your next manuscript to BioMed Central and take full advantage of:

- Convenient online submission

- Thorough peer review

- No space constraints or color figure charges

- Immediate publication on acceptance

- Inclusion in PubMed, CAS, Scopus and Google Scholar

- Research which is freely available for redistribution

Submit your manuscript at www.biomedcentral.com/submit
C Biomed Central 